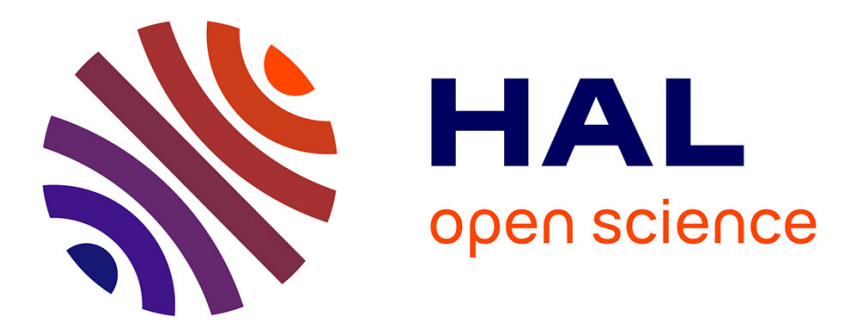

\title{
How to avoid evaporation during rheological measurements of dewatered pasty sludge at high temperature
}

Mohamed Mouzaoui, J. Baudez, Martial Sauceau, Patricia Arlabosse

\section{- To cite this version:}

Mohamed Mouzaoui, J. Baudez, Martial Sauceau, Patricia Arlabosse. How to avoid evaporation during rheological measurements of dewatered pasty sludge at high temperature. Water Science and Technology, 2019, 79 (8), pp.1503-1510. 10.2166/wst.2019.150 . hal-02120362

\section{HAL Id: hal-02120362 https://imt-mines-albi.hal.science/hal-02120362}

Submitted on 16 May 2019

HAL is a multi-disciplinary open access archive for the deposit and dissemination of scientific research documents, whether they are published or not. The documents may come from teaching and research institutions in France or abroad, or from public or private research centers.
L'archive ouverte pluridisciplinaire HAL, est destinée au dépôt et à la diffusion de documents scientifiques de niveau recherche, publiés ou non, émanant des établissements d'enseignement et de recherche français ou étrangers, des laboratoires publics ou privés. 


\title{
How to avoid evaporation during rheological measurements of dewatered pasty sludge at high temperature
}

\author{
M. Mouzaoui, J. C. Baudez, M. Sauceau and P. Arlabosse
}

\begin{abstract}
Controlling the residence time in paddle dryers and the drying efficiency imply the knowledge of rheological behaviour of highly concentrated and pasty sludge and its temperature dependency. However, because of perturbing effects such as evaporation, measurements are not fully representative of intrinsic sludge properties. Classical techniques usually considered in the literature for evaporation control are not efficient at high temperatures. This work gives a method to control the evaporation at high temperature that can be used with any commercial rheometer. The configuration concept is to prevent water loss by limiting the contact between the sheared sludge and the environment. This configuration allows preventing evaporation up to $80^{\circ} \mathrm{C}$ at least during 2 hours. Its efficiency is confirmed at different total solid (TS) contents ranging from 20 to $47 \mathrm{wt}$.\%. Key words | bad data, evaporation, high temperature, pasty sludge, rheology
\end{abstract}

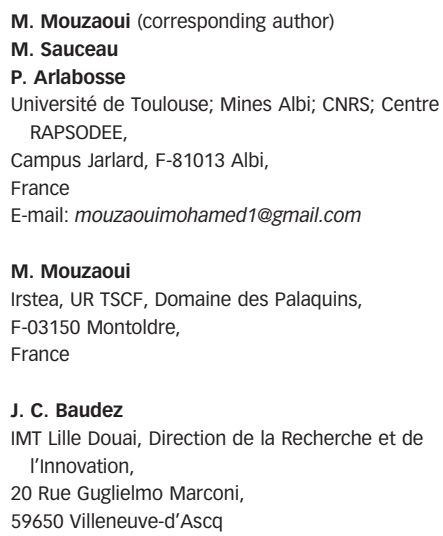

\section{INTRODUCTION}

In EU, sludge production is increasing every year and is becoming a real challenge for the waste water treatment plants (WWTP) (Fytili \& Zabaniotou 2008; Eshtiaghi et al. 20I3; European Commission 20I7). Thermal drying is one of the most commonly used operations to reduce volumes but part of the energy is unnecessarily consumed due to not optimised process (Chabrier 2007; Arlabosse et al. 20I2; Charlou et al. 20I5; Milhé et al. 20I5). The dryer energy consumption can be optimised by an accurate control of the operating parameters, among which the residence time distribution which is directly linked to the flow rates in the dryer (Djerroud 20I0; Arlabosse et al. 20I2; Charlou et al. 20I5). Controlling the residence time distribution implies the knowledge of the main rheological parameters of sludge especially for total solid contents (TS) higher than $20 \mathrm{wt} . \%$ and their temperature dependency-during drying.

However, rheological measurements are hard to perform at high TS as perturbing effects appear such as fractures and evaporation (Baudez \& Coussot 200I; Chaari et al. 2003; Charlou 2014). Indeed, at high TS, the interactions between particles are mainly frictional leading to fractures during shear, inducing bad rheological data. In a previous work, it has been shown how to correct fractures impact at ambient temperature with a well-controlled procedure allowing the exact determination of the surface really sheared, and thus, of intrinsic rheological parameters (Mouzaoui et al. 20I8).

During a long duration or high temperature tests, additional problems occur such as water loss and sample drying. Consequently, the measured rheological data are not fully representative of a controlled state of the sludge. To overcome this problem and minimize measurement errors, the most frequently used solutions in rotational rheometers (with plane-plane, coaxial-planar and coaxialplane geometries) consist in applying a Newtonian oil film around the free surfaces of sludge. With such technique, measurements have been done at temperatures up to $80^{\circ} \mathrm{C}$ for diluted sludge, that is TS $<5 \mathrm{wt} . \%$ (Ortiz et al. 1994; Briscoe et al. I998; Baudez et al. 2013b) but only up to $60{ }^{\circ} \mathrm{C}$ at higher concentrations, that is TS up to $16 \mathrm{wt} . \%$ (Baudez et al. 20I3a; Jiang et al. 20I4; Ségalen 20I5). This observation is due to the fact that rheological properties are more sensitive to water evaporation at high TS. However, the applicability of this method is limited at low experiment duration (lower than $20 \mathrm{~min}$ ) and is not adapted to pasty sludge, since fractures appear under shear 
measurements, leading to sample drainage and undesirable mass transport between the sludge and the surrounding oil layer.

The literature has underlined another solution to control the evaporation during rheological measurements consisting of keeping a saturated atmosphere during experimental tests. Attachments/additional pieces to minimize the evaporation effects have developed in that perspective. For instance, consisting of an insulated sample chamber (cover) and a vapour trap (Gans et al. 1999; Nommensen et al. 1999; Ksapabutr et al. 2004). This method has been implemented in several works, as for clay-polymer mixtures at ambient temperature (Benchabane 2006; Ebagninin 2009), diluted CMC solutions $(<5 \mathrm{wt} . \%)$ at temperatures up to $80^{\circ} \mathrm{C}$ (Benslimane 2012) or pasty sludge with TS content up to $28.5 \mathrm{wt} . \%$ at temperatures up to $60^{\circ} \mathrm{C}$ (DieudéFauvel et al. 2009; Hammadi et al. 2013; Feng et al. 2014). Later, to keep a saturated atmosphere, Quignon-Tosoni (20I5) has used an apparatus adapted from a nebulizer to the geometry of the rheometer (coaxial cylinders) and observed no change in the viscosity of clay suspensions for 24 hours at room temperature. However, a gradual evolution in sample viscosity due to evaporation was highlighted even at $40^{\circ} \mathrm{C}$ by Sato \& Breedveld (2005), leading to unrealistic rheological properties. Keeping a saturated atmosphere seems thus an efficient technique to prevent water evaporation in the case of pasty materials, but it seems to be adapted to temperatures lower than the ones used in thermal drying, typically from 90 to $120^{\circ} \mathrm{C}$.

Several authors have shown that the solubilisation of organic matter (from the solid phase to the liquid phase) at high temperature irreversibly modifies the structure of the sludge and therefore its rheology (Pevere et al. 2009; Appels et al. 2010; Farno et al. 2015, 2014). The time and the temperature of thermal treatment are the dominant factor influencing the organic solubilisation and thus the rheological parameters. Indeed, the organic matter solubilisation during thermal treatment, could reach a stable state within 30-60 minutes with respect to temperatures higher than $100^{\circ} \mathrm{C}$ (Carrère et al. 2010; Zhang et al. 2017) but ranged from hours to days at temperatures lower than $100{ }^{\circ} \mathrm{C}$ (Climent et al. 2007; Xue et al. 20I5).

Finally, the literature highlights a lack of techniques adapted to control the evaporation of water at high temperature during rheological measurements, especially for on highly concentrated suspensions such as pasty sludges. This paper aims at filling this gap by proposing a specific procedure to prevent the water evaporation at high temperatures during rheological measurements on pasty sludge. This allows to obtain intrinsic rheological parameters and thus a better understanding of pasty sludge behaviour in the dryer. The efficiency of this technique at high temperatures is first validated on sludge having $20 \mathrm{wt} . \% \mathrm{TS}$, then confirmed at 28 and $47 \mathrm{wt} . \% \mathrm{TS}$.

\section{MATERIAL AND METHODS}

\section{Sludge}

Pasty sludge was sampled at the WWTP from Albi city (France) at the outlet of the centrifuge. It is produced from extendedly aerated, thickened and digested municipal wastewater. Its initial TS (standard EN 12880:2000) was $20 \mathrm{wt} . \%$ and the volatile solid (VS, standard EN 12879:2000) content was about $63 \mathrm{wt} . \%$ (of dry weight). Samples with higher TS contents have been prepared in a filtration/compression cell inserted in a hydraulic press (Carver USA). A sludge mass of $0.8 \mathrm{~kg}$ is pressed for 48 and $72 \mathrm{~h}$ at a pressure of 30 bar. The temperature of the laboratory is maintained at $20^{\circ} \mathrm{C}$.

To avoid the problem of solubilisation during rheological tests, samples were thermally pre-treated at $90^{\circ} \mathrm{C}$ during 24 (in a hermitic container) prior to measurements. The TS and VS contents have been determined before and after the thermal treatment to check that this treatment did not alter the sludge. The Table 1 shows the result for the initial sludge.

\section{Rheological measurements}

Rheological measurements are performed with a stresscontrolled rheometer (HAAKE RheoStress 600, Thermo Scientific, Germany). The upper part supplies measurements, while the lower part is fixed. Two configurations described thereafter are implemented: plate-plate and plate-cylinder configurations.

A constant dynamic strain $(\gamma=0.3 \%)$ in the linear viscoelastic range (LVE) is applied. Viscous modulus G', elastic modulus G' and loss tangent Tan $\delta$ (viscous to elastic modulus ratio) are recorded over 3 hours. This helps at

Table 1 | Measurement of TS and VS contents before and after the thermal treatment

\begin{tabular}{lll} 
& $\begin{array}{l}\text { Before thermal } \\
\text { treatment }\end{array}$ & $\begin{array}{l}\text { After thermal } \\
\text { treatment }\end{array}$ \\
\hline TS content (wt.\%) & 20.3 & 20.4 \\
VS content (wt.\% TS) & 63.2 & 63.1 \\
\hline
\end{tabular}


evaluating the evaporation kinetics of sludge, and hence, at defining the appropriate conditions to prevent evaporation.

The TS contents of sludge is measured prior and at the end of each test. For the plate-plate configuration, the whole sample between the measuring tools is extracted while, for the plate-cylinder configuration, only part of sample below the upper plate is extracted.

\section{Plate-plate configuration}

The geometry consists of a classic serrated plate-plate with a $35 \mathrm{~mm}$ diameter (Figure 1). The gap is kept constant at $2 \mathrm{~mm}$. A peltier temperature controller is connected to the lower plate. To prevent evaporation, measurements were carried out in a vapour saturated medium by using a cover and a vapour trap (Figure 1). The cover (made of teflon) and the vapour trap (made of steel) are manufactured by Thermo Scientific. The vapour trap is connected to the shaft of the upper plate. Its principal role is to provide a tight seal between the shaft and the cover. A ring is mounted directly onto the cover: when the cover is placed, the ring lowers into the water in the vapour trap. The water on the lower plate is used to saturate air trapped in the chamber (under the cover). It can contain up to $2 \mathrm{ml}$ of water which is sufficient to saturate the air even at $80^{\circ} \mathrm{C}$. For example, based on humid air material balance calculi, the quantity of water needed to saturate the chamber at $80^{\circ} \mathrm{C}$ is close to $0.5 \mathrm{ml}$. Thereafter, only experiments without the vapour trap will be notified (no protection).

\section{Plate-cylinder configuration}

The geometry consists in a serrated upper plate $(35 \mathrm{~mm}$ diameter) coupled with a lower cylinder (36.88 mm inner diameter and $50 \mathrm{~mm}$ depth; see Figure 2). A temperatureregulated bath is connected to the lower cylinder. The sludge sample (at a constant volume for each experiment) is introduced into the measuring cylinder (Figure 2(a)). Then the upper plate is moved down in the sample so as to form a sludge ring around the upper plate of height $\mathrm{h}=$ $1.5 \mathrm{~mm}$ (Figure 2(b)). This step aims at limiting the contact between the sheared sludge and the environment. The upper plate is turned around $\phi=2 \mathrm{rad}$ (Figure 2(b)) to eliminate residual stresses generated by the surrounding sludge ring. Because of the latter step, the sample may not adhere correctly to the lower surface of the upper plate. To ensure this contact, the upper plate is lowered again of $0.5 \mathrm{~mm}$ : the new height of the sludge ring is thus $\mathrm{h}+0.5 \mathrm{~mm}$ (Figure 2(c)).

Finally, to improve the protection against evaporation, measurements are carried out in a vapour saturated medium by using the vapour trap and the cover previously described.

\section{RESULTS AND DISCUSSION}

\section{Pre-evaluation tests}

Figure 3 presents the evolution of the dimensionless elastic modulus $\left(\mathrm{G}^{\prime} / \mathrm{G}_{0}^{\prime}\right.$ where $\mathrm{G}_{0}^{\prime}$ is the initial value) and the loss tangent (Tan $\delta$ ) as function of time for triplicate using plate-plate configuration at $20{ }^{\circ} \mathrm{C}$ on a sludge at TS content of $20 \mathrm{wt} . \%$. The elastic modulus curves present the same shape but with a difference between measurements for times larger than 500 seconds. However, for the same tests, the loss tangent curves are stable and identical during the whole test. All the tests show very good repeatability and reliability. This fact is notably due to the great sensitivity of the elastic modulus to sample preparation but also to the loading of sludge in the measurements device. This is especially true at very low strains as in our case.
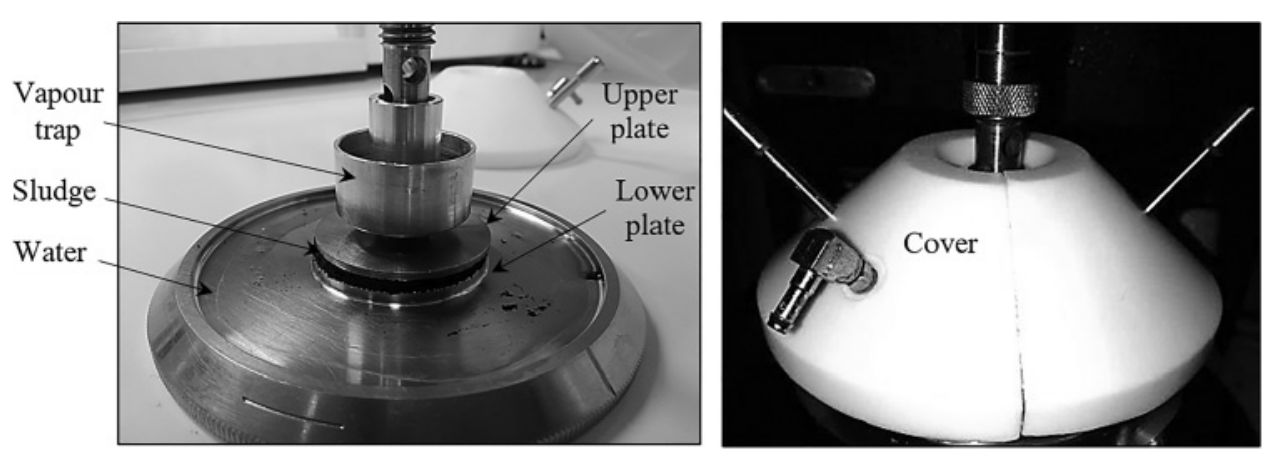

Figure 1 | Plate-plate configuration used to prevent evaporation. 

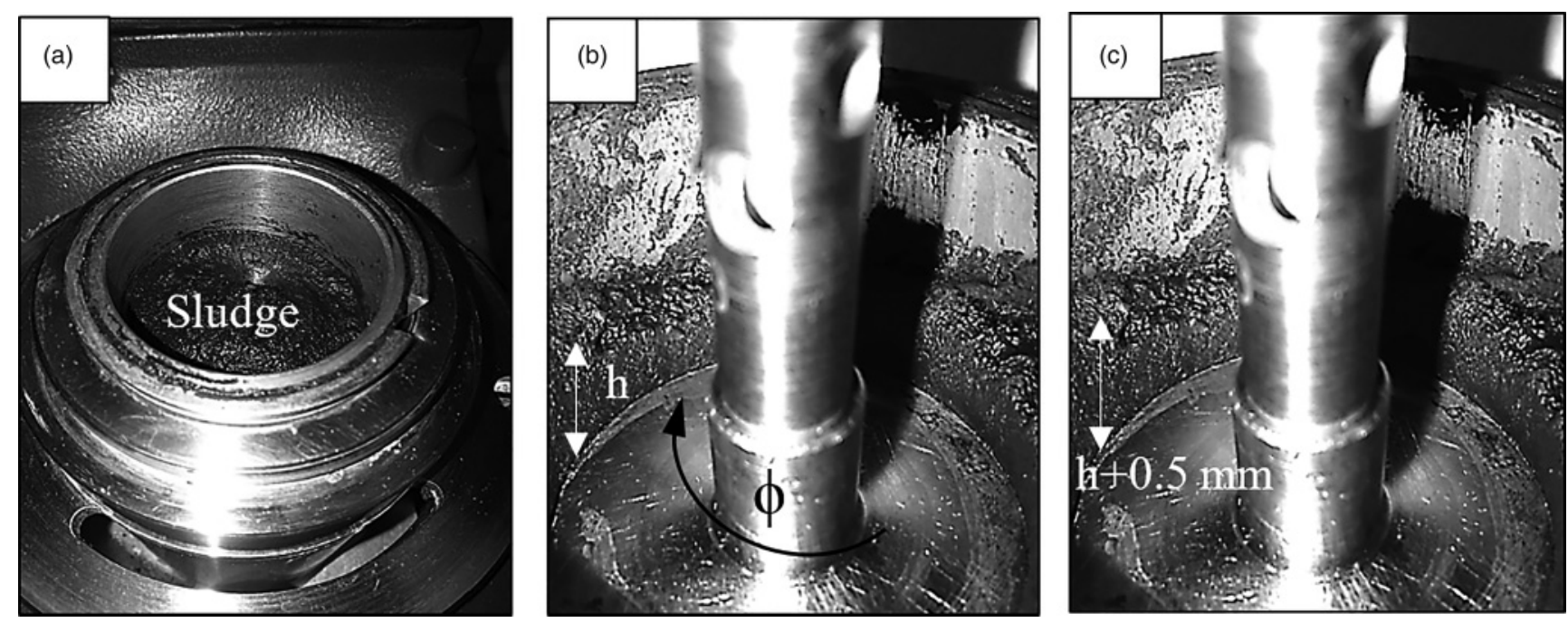

Figure 2 | Plate-cylinder configuration used to prevent evaporation.

Therefore the elastic modulus cannot be used as a reference to track the evolution of water evaporation in this study. The tracking of the loss tangent is thus more relevant to verify whether the water present in the sludge evaporates or not.

\section{Plate-plate configuration}

The Table 2 presents the increase in TS content at the end of experiment using the plate-plate configuration for sludge having initially a TS of $20 \mathrm{wt} . \%$. Without protection, the evaporation takes place even at ambient temperature from sludge free surfaces and in contact with an unsaturated atmosphere. This results in a TS increase of 19\% after 3 hours of experiment at $20^{\circ} \mathrm{C}$ and of nearly $100 \%$ after only 10 minutes of experiment at $80^{\circ} \mathrm{C}$. For a 3 hours duration at ambient temperature, no change in concentration (negligible increase of $0.2 \%$ ) is detected in a saturated atmosphere using the cover and the vapour trap. At a higher temperature of $80^{\circ} \mathrm{C}$, because of evaporation, a crusty material is formed on the free edge and as expected, the TS content of the sludge increases by $13 \%$ after only 10 minutes of experiment.

These results suggest that the combination of cover and vapour trap control the evaporation of water at ambient temperature over long periods of time, but is insufficient to perform measurements at high temperatures.

Figure 4 presents the evolution of the loss tangent as function of time using the plate-plate configuration under different conditions. Without protection at ambient temperature, the tangent loss drops significantly because of the sludge TS increase by $19 \%$. Using the cover and the vapour trap at ambient temperature, the loss tangent decreases until a critical time of about 1,000 seconds, indicating a restructuration is occurring and the material is becoming more and more elastic (Baudez 2008; Mouzaoui et al. 2018). Then, after 1,000
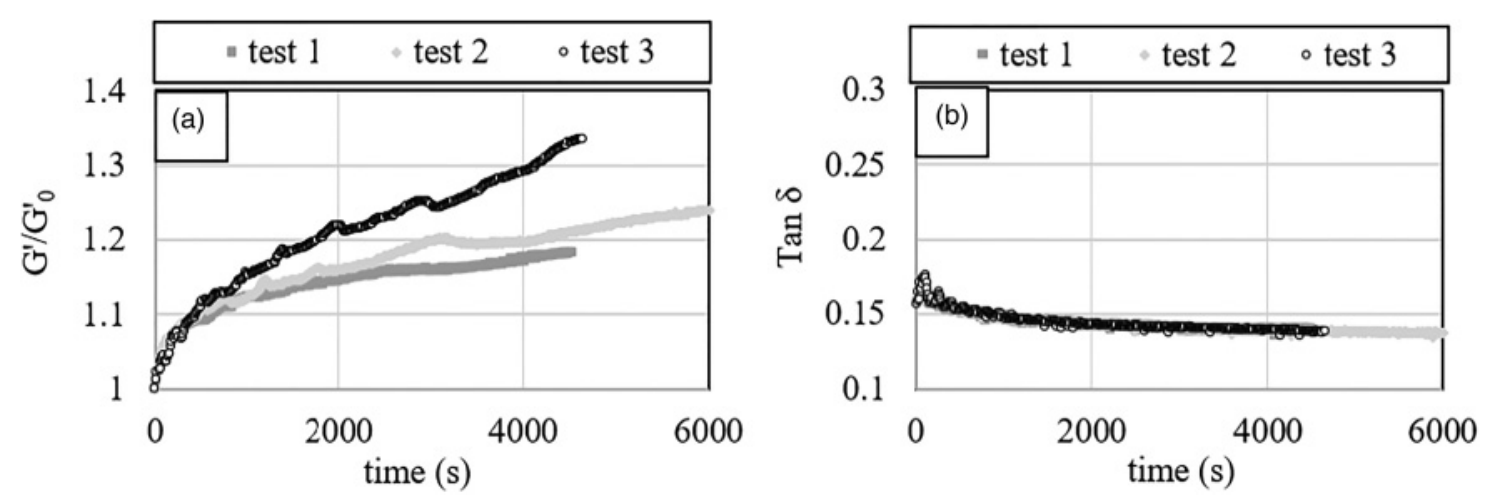

Figure 3 Evolution of the dimensionless elastic modulus (a) and the loss tangent (b) as function of time under a constant strain $\left(\gamma=0.3 \%\right.$ ) for 20 wt.\% TS sludge. $\mathrm{G}_{0}^{\prime}$ is the initial value of the elastic modulus $\mathrm{G}^{\prime}$ 


\begin{tabular}{|c|c|c|c|}
\hline Protection & Temperature & Time of experiment & TS increase (wt.\%) \\
\hline no & $20^{\circ} \mathrm{C}$ & $3 \mathrm{~h}$ & 19 \\
\hline yes & $20^{\circ} \mathrm{C}$ & $3 \mathrm{~h}$ & 0.2 \\
\hline yes & $80^{\circ} \mathrm{C}$ & $10 \mathrm{~min}$ & 13 \\
\hline
\end{tabular}

seconds, the loss tangent tends toward a plateau highlighting a stable behaviour. In fact, sludge is mainly made of water and organic polymers: during shear, there is a strong competition between colloidal forces which tend to rebuild the solid structure (physical aging) and hydrodynamic forces which tend to maintain the solid structure broken. It results in a critical strain $\gamma_{c}$ below which the solid structure rebuilds even under shear (Baudez 2008). This critical strain is without doubt higher than the strain applied in this study $\gamma=0.3 \%$, that is why sludge becomes more elastic. At $80^{\circ} \mathrm{C}$, the formation of the crusty material on the free edge leads to instabilities in the loss tangent throughout the test. It confirms that trapping saturated vapour inside the sample chamber is not sufficient to prevent sample evaporation at high temperature.

The time-dependency of sludge rheological characteristics makes the estimation of the evaporation kinetic difficult during the first 1,000 seconds. Therefore, to be able to estimate the evaporation kinetic, only the part of measurement where time is higher than 1,000 seconds, is considered, i.e., when the sludge behaviour is stable.

\section{Plate-cylinder configuration}

\section{Validation test}

Data of the plate-cylinder configuration are compared with those obtained using the plate-plate configuration at ambient temperature and in a saturated atmosphere (Figure 5).

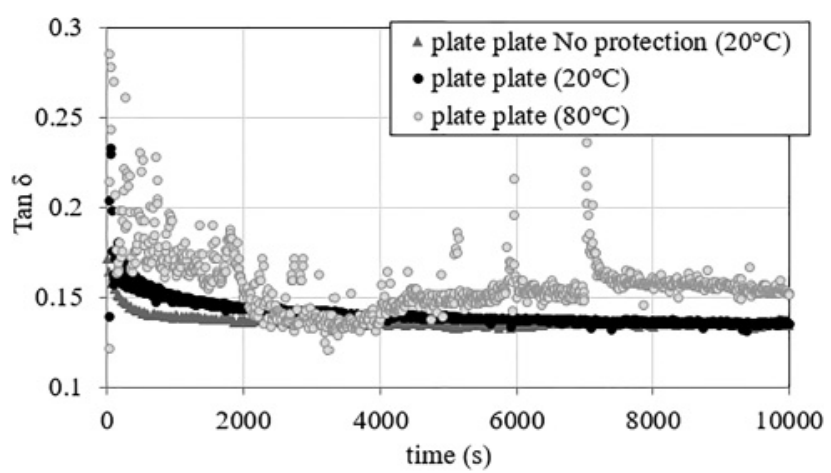

Figure 4 | Evolution of loss tangent as function of time under a constant strain $(\gamma=0.3 \%)$ for 20 wt.\% TS sludge.

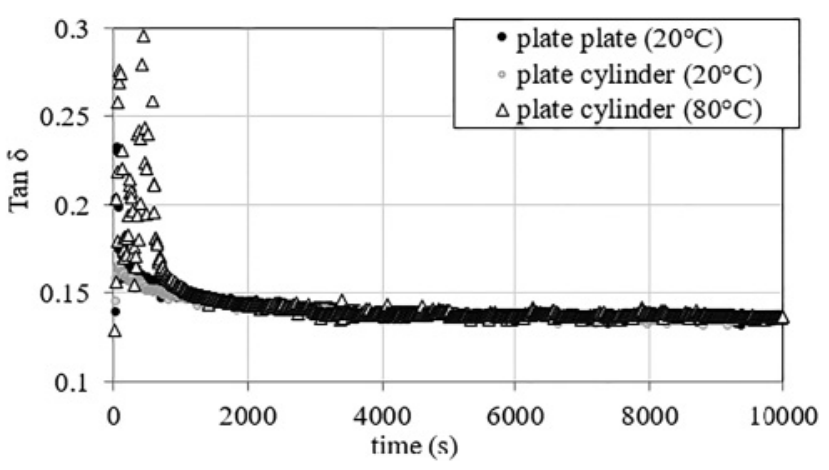

Figure 5 | Evolution of loss tangent as function of time under a constant strain $(\gamma=0.3 \%$ for sludge with $20 \mathrm{wt} . \%$ TS.

During the first 1,000 seconds, the sludge behaviour is impacted by the restructuration. Then, beyond 1,000 seconds, all curves become superimposed and almost identical. The important noise previously observed in Figure 4 at $80^{\circ} \mathrm{C}$ with plate-plate configuration is weaker.

Results in Table 3 show that TS contents of the sheared sludge is kept constant during at least 3 hours confirming an efficient control of the evaporation phenomenon. Moreover, when the measuring tools are removed away, the texture of the sheared sludge looks like soft and shiny, while the sludge surrounding the plate (the surrounding ring of sludge) seems hard and crusty playing therefore the role of a protection layer (Figure 6). Finally, this allows to validate the effectiveness of the plate cylinder configuration to prevent evaporation up to $80^{\circ} \mathrm{C}$.

To evaluate the effectiveness of the plate cylinder configuration at temperatures higher than $80^{\circ} \mathrm{C}$, the experiment was repeated for several times at a more elevated temperature that is $90^{\circ} \mathrm{C}$ (Figure 7). Large fluctuations in data are highlighted all along the experiment probably due to evaporation. It seems thus not possible to obtain reliable measurements for temperatures higher than $80^{\circ} \mathrm{C}$.

\section{Variation of TS contents at $80^{\circ} \mathrm{C}$}

As a second practical example, the behaviour of sludge at higher concentrations ( 28 and $47 \mathrm{wt} . \% \mathrm{TS}$ ) is investigated at $80^{\circ} \mathrm{C}$. Because rheological properties are very sensitive

\begin{tabular}{l|l}
$\begin{array}{l}\text { Table } 3 \mid \\
80^{\circ} \mathrm{C} \text { for } 20 \% \text { TS sludge }\end{array}$ & TS content (wt.\%) \\
Time of experiment & 20.2 \\
\hline $0 \mathrm{~h}$ & 20.2 \\
$3 \mathrm{~h}$ &
\end{tabular}




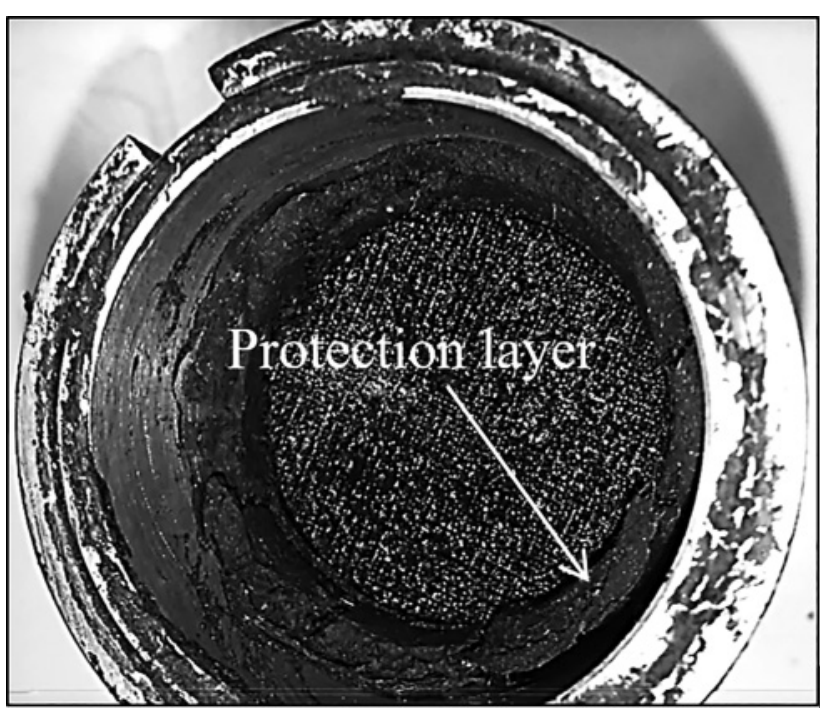

Figure 6 | Picture of the sludge after 3 hours of experiment at $80^{\circ} \mathrm{C}$ for $20 \mathrm{wt} . \%$ TS sludge.

to water evaporation at very high concentration, measurements are performed only for 6,000 seconds (Figure 8).

As expected, during the first 1,000 seconds, the loss tangent signal is dramatically noisy due to inertia and transient conduction. Then, at higher durations, whatever the TS content, curves are identical and tend toward a plateau highlighting a stable behaviour and indicating the absence of evaporation.

This configuration allows to prevent the evaporation whatever the temperature ranging from 20 to $80^{\circ} \mathrm{C}$ and thus to keep a constant state of the sludge during rheological measurements. The door is now open to define how rheological parameters of pasty sludge evolve with temperature and thus to identify a kinetic function regarding temperature changes during the drying process.

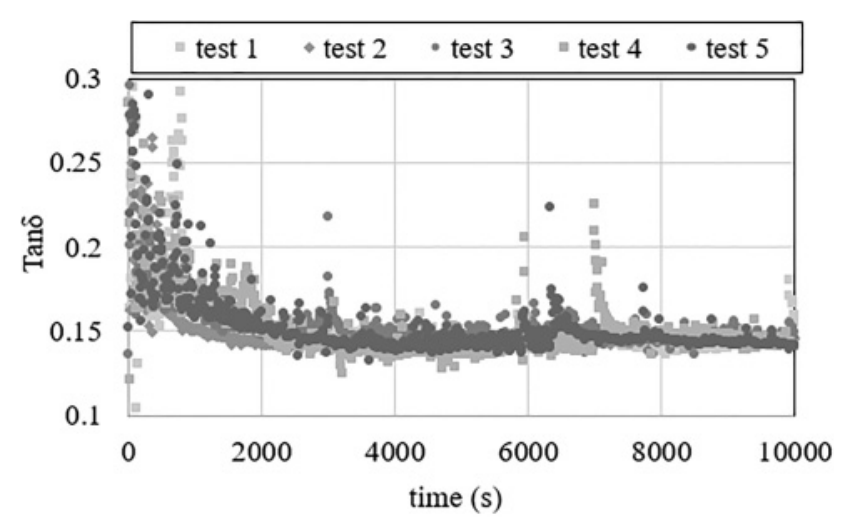

Q5 Figure 7 | Evolution of loss tangent as function of time under a constant strain $(\gamma=0.3 \%)$ at $90^{\circ} \mathrm{C}$ using a plate cylinder configuration for $20 \mathrm{wt} . \%$ TS sludge.

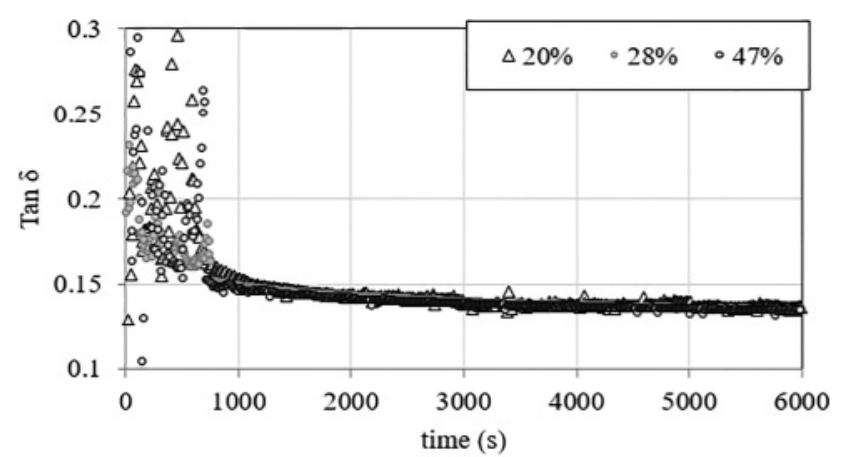

Figure 8 | Loss tangent evolution as function of time under a constant strain $(\gamma=0.3 \%)$ at Q6 $80^{\circ} \mathrm{C}$ for different TS contents.

\section{CONCLUSION}

The first part of this work demonstrates the difficulties to perform reliable rheological measurements due to the sensitivity of the elastic modulus to sample preparation and loading in the rheometer. However, the loss tangent exhibits very good repeatability and reliability and is thus used as a reference to track the evolution of water evaporation.

The second part shows how evaporation can be controlled in rotational rheometry, by implementing a simple configuration compatible with any commercial rotational rheometer. This configuration consists in an upper plate and a lower cylinder. It is based on the limitation of the contacts between the sheared sludge and the surrounding gaseous environment. It has been shown that this configuration allows preventing evaporation whatever the temperature up to $80^{\circ} \mathrm{C}$ for TS contents ranging from 20 to $47 \mathrm{wt} . \%$.

The next step of this work will aim to control both fractures and evaporation at high temperatures in order to obtain realistic rheological parameters of pasty sludges. This leads us to understand how sludge evolves in the dryer and thus to control residence time and drying efficiency.

\section{REFERENCES}

Appels, L., Degrève, J., Bruggen, B. V. d., Impe, J. V. \& Dewil, R. 20Io Influence of low temperature thermal pre-treatment on sludge solubilisation, heavy metal release and anaerobic digestion. Bioresour. Technol. 101, 5743-5748.

Arlabosse, P., Ferrasse, J. H., Lecompte, D., Crine, M., Dumont, Y. \& Léonard, A. 2012 Efficient sludge thermal processing : from drying to thermal valorisation. In: Modern Drying Technology: Energy Savings. Wiley-VCH Verlag GmbH \& Co, Germany, pp. 295-329. 
Baudez, J. C. 2008 Physical aging and thixotropy in sludge rheology. Appl. Rheol. 18, 1-8.

Baudez, J. C. \& Coussot, P. 20or Rheology of aging, concentrated, polymeric suspensions: application to pasty sewage sludges. J. Rheol. (N. Y. N. Y) 45, 1123-1139.

Baudez, J. C., Gupta, R. K., Eshtiaghi, N. \& Slatter, P. 2orza The viscoelastic behaviour of raw and anaerobic digested sludge: strong similarities with soft-glassy materials. Water Res. J. 47, 173-180.

Baudez, J. C., Slatter, P. \& Eshtiaghi, N. 20I3b The impact of temperature on the rheological behaviour of anaerobic digested sludge. Chem. Eng. J. 215-216, 182-187.

Benchabane, A. 2006 Etude du Comportement Rhéologique de Mélanges Argiles-Polymères : Effets de L'ajout de Polymères. Thèse en Mécanique des fluides, Université Louis Pasteur Strasbourg.

Benslimane, A. 2012 Rhéologie et écoulement de Fluides Chargés : Application aux Réseaux D'assainissement Urbains. Etude Expérimentale et Modélisation. Thèse en Mécanique des fluides, Université de Strasbourg.

Briscoe, B., Luckham, P. \& Zhu, S. 1998 Rheological properties of poly(ethylene oxide)queous solutions. J. Appl. Polym. Sci. 70, 419-429.

Carrère, H., Dumas, C., Battimelli, A., Batstone, D. J., Delgenès, J. P., Steyer, J. P. \& Ferrer, I. 2oro Pretreatment methods to improve sludge anaerobic degradability: a review. J. Hazard. Mater. 183, 1-15.

Chaari, F., Racineux, G., Poitou, A. \& Chaouche, M. 2003 Rheological behavior of sewage sludge and strain-induced dewatering. Rheol. Acta 42, 273-279.

Chabrier, J. P. 2007 Le séchage thermique des boues: Le développement, ses avantages et ses inconvénients, in: Journée Technique Du SIAAP.

Charlou, C. 2014 Caractérisation et Modélisation de L'écoulement des Boues Résiduaires Dans un Sécheur à Palettes. Thèse en Génie des procédés et de l'Environnement, Ecole des Mines d'Albi-Carmaux, Université de Toulouse.

Charlou, C., Milhé, M., Sauceau, M. \& Arlabosse, P. 2015 A new methodology for measurement of sludge residence time distribution in a paddle dryer using X-ray fluorescence analysis. Water Res. J. 69, 1-8.

Climent, M., Ferrer, I., Baeza, M. d. M., Artola, A., Vázquez, F. \& Font, X. 2007 Effects of thermal and mechanical pretreatments of secondary sludge on biogas production under thermophilic conditions. Chem. Eng. J. 133, 335-342.

Commission Européenne 2017 Rapport de la Commission au Parlement Européen, au Conseil, au Comité économique et Social Européen et au Comité des Régions. Bruxelles.

Dieudé-Fauvel, E., Van Damme, H. \& Baudez, J. C. 2009 Improving rheological sludge characterization with electrical measurements. Chem. Eng. Res. Des. 87, 982-986.

Djerroud, D. 2010 Modélisation Markovienne du Séchage Continu par Contact Avec Agitation. Thèse en Génie des procédés et de l'Environnement, Institut National Polytechnique de Toulouse, Université de Toulouse.

Ebagninin, K. W. 2009 Relations Structure MicroscopiqueComportement Macroscopique de Suspensions de Bentonite en Présence de Polymères. Thèse en Mécanique des fluides, Université de Strasbourg.

Eshtiaghi, N., Markis, F., Yap, S. D., Baudez, J. C. \& Slatter, P. 2013 Rheological characterisation of municipal sludge: a review. Water Res. J. 47, 5493-5510.

Farno, E., Baudez, J. C., Parthasarathy, R. \& Eshtiaghi, N. 2014 Rheological characterisation of thermally-treated anaerobic digested sludge: impact of temperature and thermal history. Water Res. J. 56, 156-161.

Farno, E., Baudez, J. C., Parthasarathy, R. \& Eshtiaghi, N. 2015 Impact of temperature and duration of thermal treatment on different concentrations of anaerobic digested sludge: kinetic similarity of organic matter solubilisation and sludge rheology. Chem. Eng. J. 273, 534-542.

Feng, G., Liu, L. \& Tan, W. 20I4 Effect of thermal hydrolysis on rheological behavior of municipal sludge. Ind. Eng. Chem. Res. 53, 85-92.

Fytili, D. \& Zabaniotou, A. 2008 Utilization of sewage sludge in EU application of old and new methods: a review. Renew. Sustain. Energy Rev. 12, 116-140.

Gans, B. d., Blom, C., Philipse, A. \& Mellema, J. 1999 Linear viscoelasticity of an inverse ferrofluid. Phys. Rev. 60, 4518-4527.

Hammadi, L., Ponton, A. \& Belhadri, M. 2013 Temperature effect on shear flow and thixotropic behavior of residual sludge from wastewater treatment plant. Mech. Time-Dependent Mater. 17, 401-412.

Jiang, J., Wu, J., Poncin, S. \& Li, H. Z. 2014 Rheological characteristics of highly concentrated anaerobic digested sludge. Biochem. Eng. J. 86, 57-61.

Ksapabutr, B., Gulari, E. \& Wongkasemjit, S. 2004 Sol-gel transition study and pyrolysis of alumina-based gels prepared from alumatrane precursor. Colloids Surfaces A 233, 145-153.

Milhé, M., Charlou, C., Sauceau, M. \& Arlabosse, P. 2015 Modeling of sewage sludge flow in a continuous paddle dryer. Dry. Technol. 33, 1061-1067.

Mouzaoui, M., Baudez, J. C., Sauceau, M. \& Arlabosse, P. 2018 Experimental rheological procedure adapted to pasty dewatered sludge up to 45\% dry matter. Water Res. J. 133, 1-7.

Nommensen, P., Duits, M., van den Ende, D. \& Mellema, J. 1999 Steady shear behavior of polymerically stabilized suspensions: experiments and lubrication based modeling. Phys. Rev. E Stat. Physics, Plasmas, Fluids, Relat. Interdiscip. Top. 59, 3147-3154.

Ortiz, M., De Kee, D. \& Carreau, P. J. 1994 Rheology of concentrated poly(ethylene oxide) solutions. J. Rheol. (N. Y. N. Y) 38, 519.

Pevere, A., Guibaud, G., Goin, E., van Hullebusch, E. \& Lens, P. 2009 Effects of physico-chemical factors on the viscosity evolution of anaerobic granular sludge. Biochem. Eng. J. 43, 231-238.

Quignon-Tosoni, J. 2015 Rhéologie des Matériaux Pâteux: Vers un Continuum des Régimes Solide et Liquide. Application aux Boues Résiduaires. Thèse en Génie des procédés, Blaise Pascal-Clermont ferrand.

Sato, J. \& Breedveld, V. 2005 Evaporation blocker for cone-plate rheometry of volatile samples. Appl. Rheol. 15, 390-397. 
Ségalen, C. 2015 Complémentarité des Propriétés Electriques et Rhéologiques Pour une Caractérisation des Boues

Résiduaires. Thèse en Génie des procédés, Université Blaise Pascal - Clermont-Ferrand.

Xue, Y., Liu, H., Chen, S., Dichtl, N., Dai, X. \& Li, N. 2015 Effects of thermal hydrolysis on organic matter solubilization and anaerobic digestion of high solid sludge. Chem. Eng. J. 264, 174-180.

Zhang, J., Xue, Y., Eshtiaghi, N., Dai, X., Tao, W. \& Li, Z. 2017 Evaluation of thermal hydrolysis efficiency of mechanically dewatered sewage sludge via rheological measurement. Water Res. J. 116, 34-43. 